\title{
A Review of Wastewater Treatment Techniques
}

\author{
Marwa Mohamed Mohamed Abdelwahed \\ Alexandria, Egypt
}

\begin{abstract}
With the rapid population growth, economic progress in addition to the global climate change (global warming), the demand for saving the limited natural resources become a huge challenge facing the world. Water is one of the natural resources that has become increasingly scarce and many of them are polluted by various human activities. Moreover, discharge untreated wastewater into surface waters such as river and lakes can causes human health problems and harm huge on the environmental through the negative impact on the wildlife, marine life and plants, as well as groundwater and surface runoff (stormwater, meltwater, rainwater) which can become polluted and can be lead also to negative economic impacts. Therefore, technologies of wastewater treatment have received global attention. The main objective of this paper is presents a literature review of some of the popular wastewater treatment techniques.
\end{abstract}

Keywords:- wastewater; sludge; Membrane; SBR

\section{INTRODUCTION}

The water that has been used and containing contaminant that affect on its quality is known as wastewater (also written waste water). Wastewater can contain various contaminants materials; physical, chemical, and biological [1]. Most of human activities that use water produce wastewater. The wastewater can divided depending on the source of it into four main groups: municipal wastewater, industrial wastewater, hospital wastewater and agriculture wastewater [2-3]. The produced wastewater from the difference resources is collecting and conveying through sewerage systems (also known as sewers systems) to the wastewater treatment plant for treatment before disposal or reuse it [4].

Municipal wastewater (sewage) is generated from homes (domestic wastewater), and also includes universities, institutions, schools, office building, airports and commercial establishments such as hotels, restaurants, and any others places that have the same type of activates [5]. Industrial wastewater is the water that drained after used in factories to make commercial products. The characteristics of this wastewater are difference depending on the types of products that are manufacture [6]. Agriculture wastewater is a used water produced as a result of agricultural activities. Such as the excess water that runs off after irrigation (it may contain chemical fertilizer and pesticides), the water used for cleaning animals (it may contain animals droppings), and the water used for cleaning the equipment (it may contain oils and grease) [7].
In many countries, the hospital wastewater is treated in the same way as a municipal wastewater. However, the researchers have been founded that the hospital wastewater contain hazardous chemical substances such as pharmaceuticals and anesthetics and discharge it into combined collection system with the municipal wastewaters and treated them in the same way is not an effective approach. Therefore, the new approach is to use separate systems for treating hospital wastewater. Some of developed countries like Denmark started to apply this system [8-9].

The main objective of wastewater treatment plants is to remove various solids contaminant contains in wastewater. The wastewater is contain of $99.9 \%$ water and $0.1 \%$ solids. These solids including suspended, dissolved, settable and floatable matter such as: biodegradable organics (toxic, trace compounds, soaps, detergents, chlorinated, aromatic solvents, carbon, fats, grease and oils), inorganic (metals, sand, ions, inorganic salts and particles), nutrients (such as nitrogen and phosphorus), biological substances and pathogenic micro-organisms which cause disease [10-11].

Moreover, there are other objectives for wastewater treatment technologies such as: improve the performance of wastewater technologies that achieve the environmental protection, protect public health, high quality of treatment, reduce the amount of mechanical required equipment, reduce the operation and maintenance cost, less consumption of energy, and reduce emissions. In addition to energy generation potential, and also possibility of reuse the treated water or sludge in different fields such as agriculture and construction or producing other reusable products [12].

The most popular technology for wastewater treatment is a conventional activated sludge. This technique has been discovered to achieve the objectives for wastewater treatment. But this system is suffer from some problems for instance needing for large open reactors which mean large space requirements, high energy consumption, producing large content of sludge which causes problems for disposal [13].

So, many researchers over the years are working to achieve these objectives and for that others methods have surfaced as an improving of conventional activated sludge processes. These technologies are consider alternative technologies to activated sludge processes or they are integrating with it. For instance: anaerobic-aerobic fixed film bioreactor system, anaerobic-anoxic-aerobic system, expanded granular sludge bed bioreactor, anaerobic/aerobic moving biofilm reactor system, anaerobic/aerobic membrane bioreactor system, sequential batch reactor system or sequencing batch reactors, rotating biological 
contactors, anaerobic/aerobic/anoxic sequencing, natural and artificial wetland systems [14].

\section{HISTORY OF WASTEWATER TREATMENT}

The solution to disposal of wastewater was spreading the wastewater over the land, which cause significant problems for the public health and adverse environmental impacts. Methods of wastewater treatment were developed in 1800 s, by replaced open sewage ditches by buried sewage drains. Wastewater was discharged through theses drains without treatment [15].

After many years, around 1887, the first sand filter was used (primary treatment). Depending on the level of the water, sand filters are built above ground or often partially or completely buried in the ground. It is working by flowing the wastewater through the sand filter, the contaminants stick to the surface of the sand, reducing numbers of bacteria, and most of the solids are removing. Wastewater treated by sand filtration is usually without smell or color [16].

After, the German civil engineer scientist Dr. Karl Imhoff in 1905, who worked on develop the primary treatment technology for enhance the solids settling and separation through using a single tank (known as Imhoff tank) [17]. Afterward in 1913, using chlorine was started for wastewater treatment [18].

As a result of continuous developments and researches to improve wastewater treatment technologies, two researchers disclosed about the activated sludge process in 1914. That happened after returning Dr. Gilbert Fowler in the University of Manchester from his trip to USA and visited the Lawrence Experimental Station in Massachusetts for testing possible wastewater treatment procedures. The two researcher are Eng. Edward Ardern and his co-worker Eng. William Lockett who were working for Manchester Corporation Rivers Department at Davyhulme wastewater treatment plant in England - United Kingdom [19]. Since that time, the activated sludge process has been the most common operation in wastewater treatment.

Also, in late 1920s, the concept of sequencing batch reactors using single reactor tank were found by Arden and Lockett in England, but it populated in early 2000s after the improvement of aeration technology has been applied in the and operator's automatic control [20].

Nevertheless over than 100 years and because of the disadvantages in the performance of activated sludge processes, poor biomass settling properties, the needing large area for reactor (aeration tank) and the energy consumption, many researchers have been worked on modifying and enhancing the performance of activated sludge process. One of this attempt was happened in the late of 1960s, when the anaerobic granules was recognized by Professor Gatze Lettinga, from Wageningen University in the Netherlands, when he observed that aerobic bacteria and microorganisms in activated sludge can spontaneously grouped together to form granules under certain conditions [21].

And also in 1979 the new technology for nitrogen removal from wastewater was predicted by Gist Brocades (major international biotechnology company) in Delft, Anammox (anoxic ammonium oxidation), then it developed by Delft University of Technology (TU Delft). The researchers are looking to integrate the two technology together and the researches still are working [22].

By 2002, Professor Van Loosdrecht from Delft University and his team were cooperate with engineering consultancy Royal HaskoningDHV (engineering consultancy) in the Netherlands and they had established stable laboratory aerobic sludge. This technology take the name "Nereda" as a modification of the activated sludge process [23].

At the same time, by the late 1960s, for improving the conventional activated sludge technique by connected it with membrane reactor, are announced by Rensselaer Polytechnic Institute, New York and Dorr Oliver Inc. Milford, USA. Also late 1970s side stream membrane was made by Dorr-Oliver. Moreover in the mid of $1980 \mathrm{~s}$, submerged membranes, firstly introduced by Yamamoto from university of Tokyo. But, the membrane technique did not received the desired popularity because of the cost of membrane cleaning. Whereas, if the cleaning is not happen periodically (membrane fouling), it will affect on its performance [24].

\section{WASTEWATER TREATMENT THECHNIQES}

There are many systems are used to treat the different types of wastewater. In the following an abbreviation explanations for some popular of these techniques.

\section{A. Conventional Activated floc Sludge Floc Process \\ Conventional Activated Sludge consist of three main phases: preliminary treatment, the main purpose of this step is protect the equipment of wastewater plant such as pumps by removing solids using screening, grit chambers and flotation oils and fat. The second stage is primary treatment, where settleable solids are removed through sedimentation and by using filters to separate solid contaminants from water [25]. Following by the secondary treatment, the goal from this stage is remove the suspended and dissolved solids by using aeration tank also known as bio-reactor tank (biological process). The microorganism (bacteria, protozoa, etc.) use the wastes as a food and remove organic contaminants in wastewater using oxygen [26].}




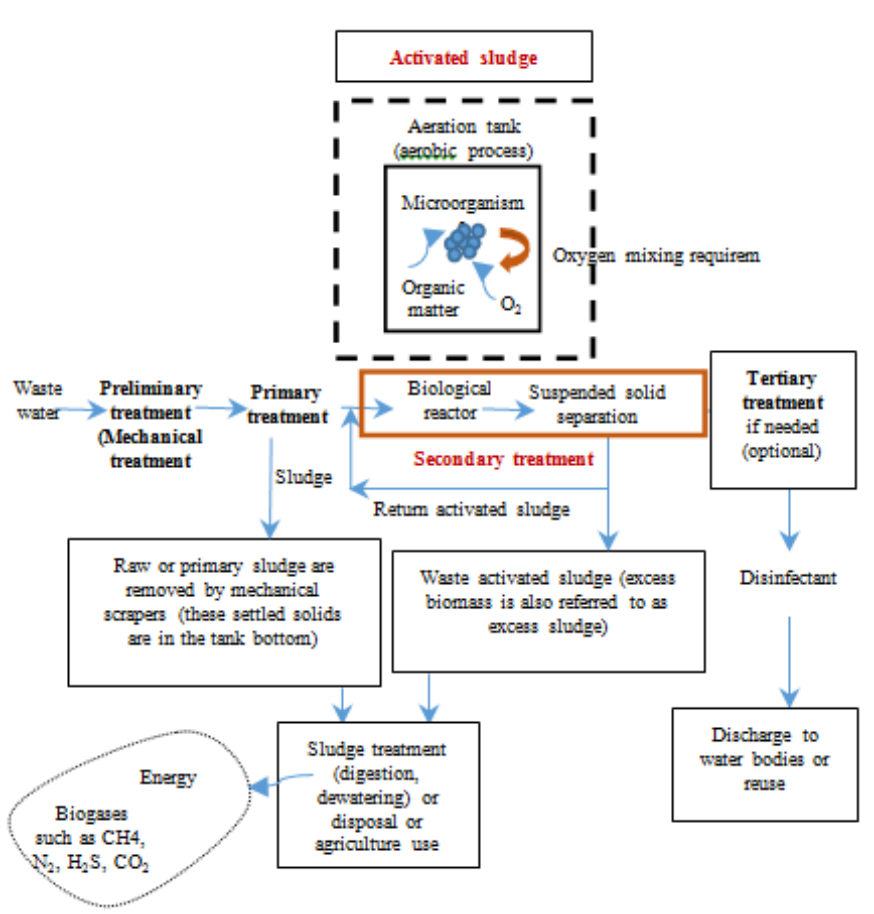

Fig 1:- Conventional Activated Sludge Plan

However, the aeration tank has a disadvantage of insufficient removal of nitrogen and phosphorus. The aeration tank is following by settlement tank for solidliquid separation. Therefore, the tertiary treatment (Advanced treatment) is following the sedimentation tank, where the inorganic contaminants such as nutrients (e.g. phosphorus, nitrogen, phosphate, ammonium and nitrogen) and all suspended and organic matter are remove from wastewater using chemical or using physical separation methods such as membrane. This step is optional if the water need to improve its quality. In this stage also the water color is remove [27]. The (Fig. 1) shows the contents of the conventional activated sludge plant.

\section{B. Sequencing Batch Reactors (SBR)}

The system consist from four Sequencing phases or steps using a single tank (batch reactor). The solid-liquid separation is carried out in the same tank, which mean there is no need for sedimentation tank and that save space [28]. The (Fig. 2) shows the place of SBR tank in the wastewater treatment plant.



Fig 3:- The stages in the SBR tank

The first step is filling the tank with the waste water (known also as anoxic phase), the mechanical mixing is providing without oxygen. Then the second step is an aeration phase (biological treatment), where the oxygen is injected and mixing mechanically with organic matter and microorganism. During the anaerobic condition, the phosphorus can removal. Also, when the anoxic condition happen, the nitrogen can removal. During this step there is no wastewater enters to the tank. Following by third step, settle phase, during this phase, biomass is allowed to settle and the solid-liquid separate. Then discharge the treated water during the decant step [29]. The (Fig. 3) shows the SBR stages.

\section{Membrane Bioreactor/Filtration System}

Membrane separation techniques are barriers or films of the porous synthetic materials such as polymers, plastic, metals and ceramics, which allow only to contaminated fluid to pass through. Whereas the ultrafiltration (UF) membranes, microfiltration (MF) membranes, nanofiltration membranes (NF) and reverse osmosis membranes (RO) are separate microorganisms (bacteria and viruses) and suspended solids from the treated wastewater. Which mean the Membrane provides solid liquid separation and therefor is no required for sedimentation tank (settling tank) to separate the sludge from the effluent and reduce the concentrations of volume sludge production [30].

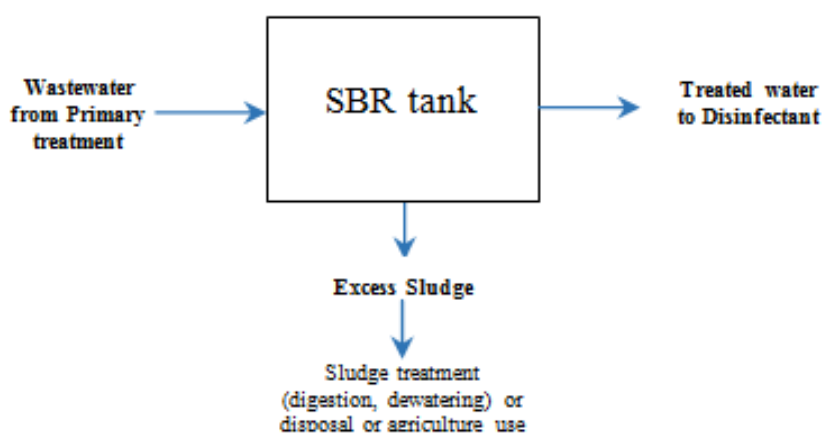

Fig 2:- Place of SBR in the plant 




Fig 4:- External Membrane Process

The membrane has four types: hollow fiber, spiral wound, flat sheet (plate and frame), tubular, according to membrane form. Also the membrane can divided in two types: (submerged (internal also known as immersed; placed in the biological tank) and side stream (external; placed next to the biological tank) according to their location. The membrane biological reactor system can be an anaerobic membrane bioreactor (it is not require oxygen and applied to wastewater with COD > $4000 \mathrm{mg} / \mathrm{l}$ ) or an aerobic membrane bioreactor (require oxygen and applied to wastewater with COD < $1000 \mathrm{mg} / \mathrm{l})$. Recently the researchers are combining between both of them [31]. The (Fig. 1) and (Fig. 2) show the processing of external membrane and internal membrane consequently.

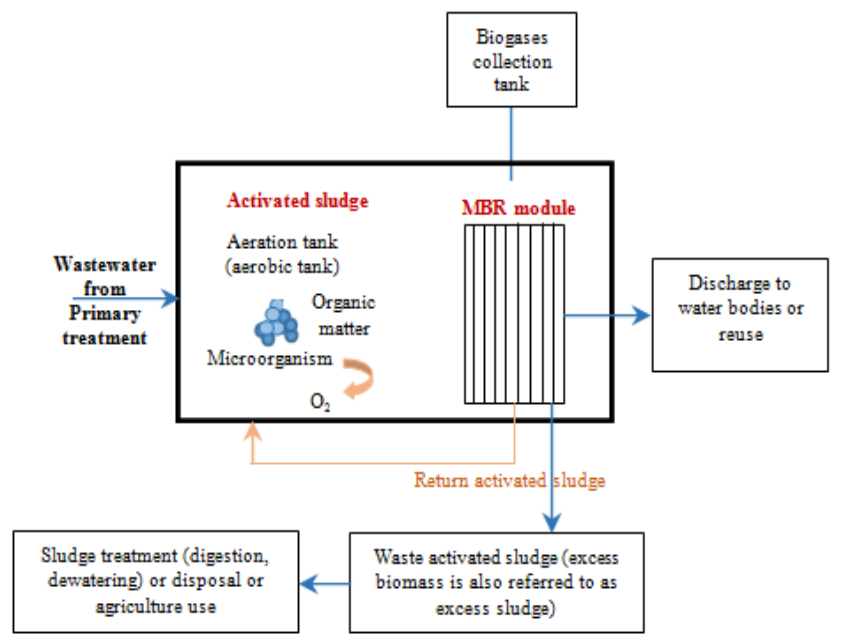

\section{Aerobic Granular Sludge Processes}

Accordingly for the advantages of anaerobic granules than conventional activated, around 2005, aerobic granular sludge was started to published and use instead of the conventional activated sludge process or integrated with it or other processes [32].

In the aerobic granular sludge processes, the microorganism (bacteria and protozoa) remove organic contaminants in wastewater without the use of a carrier material, on which microorganisms settle on, which mean reducing energy consumption. The aerobic granular sludge processes has excellent settling properties comparing to conventional activated sludge processes which leading to prompt liquid-solids separation. Moreover, the reduction in footprint and less chemical consumption. The Nereda technology needs only to one tank and it consisting on three phases: anaerobic fill and decant phase, aeration and settling and in this process there is no need for sludge recirculation [33].

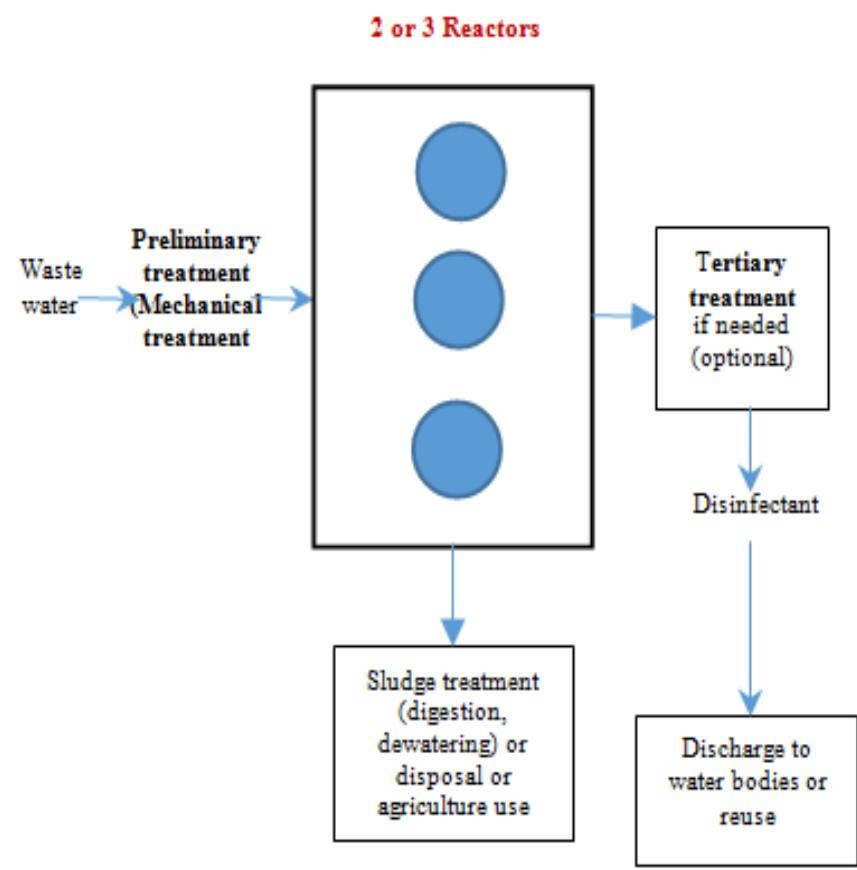

Fig 6:- Aerobic Granular Sludge Processes

\section{CONCLUTION}

Four wastewater technologies have been investigated as briefly reviewed. Although wastewater treatment technology has been widely concerned and studied by researchers and they have made great progress, there still need to study the relation between the environment and the efficiency of technology. In addition, it is necessary to take in consideration, fundamental to design and choose the appropriate wastewater treatment technique without ignoring the economically effective.

Fig 5:- Internal Membrane Process 


\section{REFERENCES}

[1]. A. Mattsson, A. Finnson ,D. I'Ons, "Heavy metal content of Swedish municipal wastewater sludge status and goals", Water Science \& Technology, vol. 76, no. 4 , pp.869-876, 2017.

[2]. R. Kumar, R.D. Singh and K.D. Sharma, "Water resources of India", Current Science, vol. 89, no. 5, pp. 794-811, 2005.

[3]. C. Dagot, M.C. Ploy, "Quantitative and qualitative impact of hospital effluent on dissemination of the integron pool", ISME Journal, vol. 8, no. 4, pp. 768 777, 2014.

[4]. J. I. Wilson, P. J. Smith, A. Witt and M. E. Canning,"Wastewater Collection System Optimization for Cost-Effective and Sustainable Capital Improvement Planning”, Water Practice \& Technology, vol. 5, no. 4, 2010.

[5]. Y. J. Chan, M. F. Chong, C. L. Law, D.G. Hassell, “A review on anaerobic-aerobic treatment of industrial and municipal wastewater", Chemical Engineering Journal, vol. 155, pp. 1-18, 2009.

[6]. L. Yang, D.H. Han, B.M. Lee, J. Hur, "Characterizing treated wastewaters of different industries using clustered fluorescence EEM-PARAFAC and FT-IR spectroscopy: Implications for downstream impact and source identification", Chemosphere, vol. 127, pp. 222-228, 2015.

[7]. J. Blanca, "Treatment technology and standards for agricultural wastewater reuse: A case study in Mexico", Irrigation and drainage, vol. 54, pp. 23S33S, 2005.

[8]. Grundfos Biobooster $\mathrm{A} / \mathrm{S}$, "Full scale advanced wastewater treatment at Herlev Hospital - Treatment performance and evaluation", Report prepared by DHI, 2016.

[9]. B. Pauwels, W. Verstraete, "The treatment of hospital wastewater", Journal of Water \& Health, vol. 4, pp. 405-416, 2006.

[10]. D. Johnson, "Wastewater Management in the Metropolitan North Georgia Water Planning District", Proceedings of the WEF Collections Systems Conference, Atlanta, Georgia, May 1-4, 2016.

[11]. S. Quadros, M. Joao Rosa, H. Alegre, C.A. Silva, "Performance indicators system for urban wastewater treatment plants" Water Science Technology, vol. 62, pp. 2398-2407, 2010.

[12]. A. Kelessidis, AS. Stasinakis, "Comparative study of the methods used for treatment and final disposal of sewage sludge in European countries", Waste Managment, vol. 32, no. 6, pp. 1186-95, 2012.

[13]. T. S. Chung, X. Li, R. C. Ong, Q. Ge, H. Wang and G. Han, "Emerging Forward Osmosis (FO) Technologies and Challenges Ahead for Clean Water of Energy Application", Current Opinion in Chemical Engineering, vol. 1, pp. 246-257, 2012.

[14]. S. Longo, B.M. d'Antoni, M. Bongards, A. Chaparro, Cronrath, F. Fatone, J.M. Lema, M. Mauricio-Iglesias, A. Soares and A. Hospido, "Monitoring and diagnosis of energy consumption in wastewater treatment plants", A state of the art and proposals for improvement. Applied Energy, vol. 179, pp. 12511268, 2016.

[15]. GEO, "Ground Control for Slurry TBM Tunnelling, GEO Report No. 249, Geotechnical Engineering Office", Hong Kong, pp. 37, 2008.

[16]. "P. Lens, G. Zeeman, G. Lettinga, "Historical aspects of wastewater treatment", Decentralised sanitation and reuse: concepts, systems and implementation", IWA Publishing, 2007.

[17]. J.E. McCauley, "The West side sewage treatment works of the Sanitary district of Chicago", Professional Degree Theses, 1930.

[18]. G. B. Gascoigne, "Chlorination of Sewage and Sewage Effluents", Sewage Works Journal, vol. 3, no. 1, pp. 38-49, 1931.

[19]. American Public Health Association, American Water Works Association, and Water Environment Federation, "Standard Methods for the Examination of Water and Wastewater", 22nd Edition, 2012.

[20]. M. Smyth and N.J. Horan, "Sequencing batch reactor - past, present and future", $8^{\text {th }}$ Europian waste water management conference, 7- 8 Oct 2014, Manchester, UK.

[21]. M. de Kreuk, M.C.M. van Loosdrech, "Formation of aerobic granules with domestic sewage", Journal of Environment Engineering, vol. 132, no. 1, 2007.

[22]. B. Kartal, J.G. Kuenen, M. Van Loosdrecht, "Sewage Treatment with Anammox. Science", vol. 328, pp. 702-703, 2010.

[23]. H.F. Roest, M.C.M. Van Loosdrecht, E. Langkamp, C. Uijterlinde, "Recovery and reuse of alginate from granular Nereda sludge", Water 21, pp. 48, 2015.

[24]. J. Jyoti, D. Alka and S. J. Kumar, "Application of Membrane-Bio-Reactor in Waste-Water Treatment: A Review", International Journal of Chemistry and Chemical Engineering, vol. 3, no. 2, pp. 115-122, 2013.

[25]. P. Wang, Z. Yu, R. Qi, and H. Zhang, "Detailed comparison of bacterial communities during seasonal sludge bulking in a municipal wastewater treatment plant", Water Research, vol. 105, pp. 157-166, 2016.

[26]. D. Shu, Y. He, H. Yue, and Q. Wang, "Microbial structures and community functions of anaerobic sludge in six full-scale wastewater treatment plants as revealed by 454 high-throughput pyrosequencing", Bioresource Technology, vol. 186, pp. 163-172, 2015.

[27]. Q. Ma, Y. Qu, W. Shen, Z. Zhang, J. Wang, Z. Liu, D. $\mathrm{Li}, \mathrm{H}$. Li and J. Zhou, "Bacterial community compositions of coking wastewater treatment plants in steel industry revealed by Illumina high-throughput sequencing," Bioresource Technology, vol. 179, pp. 436-443, 2015.

[28]. J. Ma, L. Yu, C. Frear, Q. Zhao, X. Li and S. Chen, "Kinetics of psychrophilic anaerobic sequencing batch reactor treating flushed dairy manure", Bioresour Technol, vol. 131, pp. 6-12, 2013.

[29]. U.J. Ndon, , J.C. Zhao and M.L. Siguan, "Modeling and computational simulation of dilution and biochemical materials balance equations for the partially emptied batch reactors", 
Biotechnology and Applied Biochemistry, vol. 136, no. 1, pp. 97, 2007.

[30]. S.M. Riley, D.C. Ahoor, J. Regnery and T.Y. Cath, "Tracking oil and gas wastewater-derived organic matter in a hybrid biofilter membrane treatment system: A multi-analytical approach", Science of the Total Environment, pp.613-614, 2018.

[31]. A. Maskooki, S.A. Mortazavi and A. Maskooki, "Cleaning of spiralwound ultrafiltration membranes using ultrasound and alkaline solution of EDTA", Desalination, vol. 264, pp. 63-69, 2010.

[32]. H. F. Roest, M.C.M. Van Loosdrecht, E. Langkamp, C. Uijterlinde, "Recovery and reuse of alginate from granular Nereda sludge", Water 21, pp. 48, 2015.

[33]. H.F. Roest, L.M. Bruin, G. Gademan, F. Coelho, "Towards sustainable waste water treatment with Dutch Nereda technology", Water Practice and Technology, vol. 6, no. 3, 2011 